\title{
Brusellozun ilk manifestasyonu olarak ortaya çıkan epididimo-orșit olgularının semptom ve bulguları non-spesifik epididimo-orșitten farklı mıdır?
}

\author{
Are the symptoms and signs of brucella epididimo-orchitis as the first \\ presenting sign of brusellosis different from non-spesific epididimo-orchitis?
}

\author{
Ozan Efesoy ${ }^{1}$, Barıș Saylam¹, Selahittin Çayan²(1)
}

\section{öz}

AMAÇ: Brusellozun ilk manifestasyonu olarak ortaya çıkan epididimo-orşiti (BEO) non-spesifik epididimo-orşitten (NSEO) ayırmak oldukça güçtür. Bu olgularda tanı ve tedavinin gecikmesi, infertilite ve orşiektomi gibi sonuçlar doğurabilen testiküler hasara neden olmaktadır. Çalışmamızın amacı BEO’nun klinik, laboratuvar ve radyolojik bulgularının NSEO'dan farklılıklarının değerlendirilmesidir.

GEREÇ ve YÖNTEM: Ocak 2010-Haziran 2018 tarihleri arasında kliniğimizde epididimo-orşit tanısı konulan 164 hastanın kayıtları retrospektif olarak değerlendirildi. Epididimo-orşit tanısı klinik ve laboratuvar bulguları ile ultrasonografik değerlendirme sonucunda konuldu. BEO tanısı ise bu bulgulara ek olarak standart tüp aglütinasyon testinde $\geq 1 / 160$ titre değeri ve/veya pozitif kan kültürü olarak tanımlandı. BEO tanısı konulan 14 olgudan daha önce bruselloz tanısı almış 5 olgu çalışma dışında bırakıldı ve epididimo-orşit ile ortaya çıkan 9 bruselloz olgusunun klinik, laboratuvar ve radyolojik bulguları aynı yaş grubundaki 34 NSEO'lu olgu ile karşılaşıırıldı.

BULGULAR: Tanı anında olguların yaş ortalaması BEO ve NSEO gruplarında sırası ile $33,44 \pm 9,81$ ve $34,76 \pm 10,09$ olarak bulundu ( $p=0,728)$. Brusella için risk faktörlerinin varlığı dışında iki grup arasında klinik, laboratuvar ve radyolojik bulguların sıklığı bakımından istatistiksel olarak anlamlı farklılık saptanmadı. Brusella için risk faktörleri BEO'lu olguların sekizinde $(\% 88,9)$, NSEO'lu olguların ise beşinde $(\% 14,7)$ saptandı $(\mathrm{p}<0,001)$. Ayrıca, istatistiksel olarak anlamlı olmamakla beraber, artralji ve $5 \mathrm{mg} / \mathrm{dL}$ 'nin üzerinde serum $\mathrm{C}$ reaktif protein yüksekliği sıklığının BEO'lu, dizüri, piyüri ve lökositozun ise NSEO'lu olgularda anlamlılık eğilimi düzeyinde daha sık görüldüğü saptandı ( $p$ değerleri sırası ile $0,073,0,089,0,069,0,069$ ve 0,058 )

SONUCุ: Brusellozun ülkemizde halen endemik olarak bulunması nedeniyle epididimo-orşitli olgularda brusella ayırıcı tanıda akılda tutulmalı ve bu olgulardan öykü alınırken bruselloz risk faktörleri mutlaka sorgulanmalıdır. Ayrıca, dizüri, piyüri ve lökositozu olmayan, artraljinin eşlik ettiği epididimo-orşit olgularında $\mathrm{BEO}$ ayııııı tanısı açısından daha dikkatli olunmalıdır.

Anahtar Kelimeler: Ayırıcı tanı, brusella, epididimo-orşit

\section{ABSTRACT}

OBJECTIVE: Brucella epididymo-orchitis as the first presenting sign of brucellosis (BEO) is difficult to separate from non-specific epididymo-orchitis (NSEO). In these cases, delayed diagnosis and treatment causes testicular damage that may lead to infertility and orchiectomy. The aim of this study was to investigate whether or not the clinical, laboratory and radiological findings of BEO different from NSEO.

MATERIAL and METHODS: In this retrospective study, we evaluated the medical records of 164 patients who diagnosed with epididymo-orchitis in our clinic between January 2010 and June 2018. The diagnosis of epididymo-orchitis was based on clinical and laboratory findings and ultrasonographic examination. High agglutination titers $(\geq 1 / 160)$ and/or positive blood cultures were accepted as the main criteria for the diagnosis of brucellosis. Five patients who were previously diagnosed as brucellosis were excluded from the study and the clinical, laboratory and radiological findings of 9 cases of BEO were compared with 34 NSEO cases in the same age group.

RESULTS: The mean age of cases at diagnosis was $33.44 \pm 9.81$ and $34.76 \pm 10.09$ in the BEO and NSEO groups, respectively ( $\mathrm{p}=0.728$ ). There were no significant differences between two groups in terms of clinical, laboratory and radiological findings, except one. Risk factors for brucella were detected in $8(88.9 \%)$ of BEO group and in $5(14.7 \%)$ of NSEO group $(\mathrm{p}<0.001)$. Although not statistically significant but at the level of borderline significant trend, it was found that the ratio of arthralgia and serum CRP levels $>5 \mathrm{mg} / \mathrm{dL}$ more frequent in $\mathrm{BEO}$ group and the ratio of dysuria, pyuria and leukocytosis more frequent NSEO group ( $\mathrm{p}$ values $0.073,0.089,0.069,0.069$ and 0.058 , respectively).

CONCLUSION: Brucellosis should be kept in mind in patients with epididymoorchitis and the risk factors for brucellosis should be questioned in these patients. In addition, in patients with epididymo-orchitis with arthralgia without dysuria, pyuria and leukocytosis should more be paid attention to the differential diagnosis of BEO.

Keywords: Brucellosis, differential diagnosis, epididymo-orchitis
'Mersin Şehir Eğitim ve Araştırma Hastanesi, Üroloji Kliniği, Mersin, Türkiye ${ }^{2}$ Mersin Üniversitesi Tıp Fakültesi, Üroloji Anabilim Dalı, Mersin, Türkiye

Yazışma Adresi/ Correspondence:

Uzm. Dr. Ozan Efesoy

Mersin Şehir Eğitim ve Araștırma Hastanesi, 33240 Mersin, Türkiye

Tel. $\quad+905057462494$

E-mail: oefesoy@yahoo.com

Geliş/ Received: $\quad 30.09 .2018$

Kabul/ Accepted: $\quad 25.10 .2018$

\section{Gíriș}

Bruselloz, hayvanlardan insanlara bulaşan, çeşitli doku ve organları tutan, hafif belirtilerden ağır klinik tablolara kadar seyredebilen, belirti ve bulguları spesifik olmayan ve bu nedenlerle birçok hastalığı taklit edebilen sistemik bir hastalıktır. Dünya Sağlık Örgütü (DSÖ) verilerine göre dünyada en sık rastlanan bakteriyel zoonoz olan bruselloz 
gelişmiş ülkelerin çoğunda eradike edilmesine rağmen ülkemizin de içinde bulunduğu Akdeniz havzası ülkeleri, Basra körfezi, Hindistan, Meksika ile orta ve güney Amerika’nın bir kısmında halen endemik olarak görülmektedir. ${ }^{[1]}$

Epididimo-orşit brusellozun önemli bir klinik manifestasyonudur ve brusellozlu olguların yaklaşık \%10'unda görülmektedir. ${ }^{[2]}$ Bruselloz olduğu bilinen veya bruselloz düşündüren semptom ve bulguların eşlik ettiği epididimo-orşitli olgularda etiyolojide bruselloz hemen akla gelse de brusellozun ilk manifestasyonu olarak izole epididimo-orşit (BEO) görülen olguları non-spesifik epididimoorşitli (NSEO) olgulardan ayırmak oldukça güçtür. Zamanında ve uygun tedavi edilmeyen BEO orşiektomiye varan sonuçlar doğurabildiği gibi spermatozoaya karşı otoimmünizasyonun indüklenmesine yol açarak infertiliteye de neden olabilmektedir. ${ }^{[3-5]}$ Çalışmamızın amacı brusellozun ilk manifestasyonu olarak ortaya çıkan epidimo-orşitin klinik, laboratuvar ve radyolojik bulgularının NSEO'dan farklılıklarının değerlendirilmesidir.

\section{GEREÇ VE YÖNTEM}

Çalışma için Mersin Üniversitesi Klinik Araştırmalar Etik Kurulundan onay alındı (Retrospektif çalışma olduğundan hasta aydınlatılmış onamına ihtiyaç yoktur). Ocak 2010-Haziran 2018 tarihleri arasında polikliniğimize akut skrotum bulguları (ağrı, şişlik ve kızarıklık) ile başvuran ve epididimo-orşit tanısı konulan 164 hastanın kayıtları retrospektif olarak değerlendirildi. BEO tanısı konulan 14 olgudan daha önce Bruselloz tanısı almış 5 olgu çalışma dışında bırakıldı ve epididimo-orşit ile ortaya çıkan 9 bruselloz olgusunun klinik, laboratuvar ve radyolojik bulguları aynı yaş grubundaki 34 NSEO'lu olgu ile karşılaştırıldı.

Epididimoorşit tanısı klinik (akut skrotum bulguları), laboratuvar (lökositoz, eritrosit sedimentasyon hızı [ESH] ve $\mathrm{C}$ reaktif protein [CRP] yüksekliği) ve radyolojik (skrotal renkli Doppler ultrasonografi [RDUS]'de epididim/testis boyutlarında ve kanlanmasında artış, parankim ekosu değişiklikleri) bulgularla konuldu. BEO tanısı ise bu bulgulara ek olarak standart tüp aglütinasyon testinde $\geq 1 / 160$ titre değeri ve/veya pozitif kan kültürü olarak tanımlandı.

Sürekli değişkenlere ait tanımlayıcı istatistikler ortalama \pm standart sapma, kategorik değişkenlere ait tanımlayıC1 istatistikler ise frekans ve yüzde (\%) olarak sunuldu. $\mathrm{BEO}$ ve NSEO'lu olguların yaş ortalamaları independent samples t-test, gruplar arasında klinik belirti ve bulguların sıklık yüzdelerinin karşılaştırılmasında ise frekans dağılımına göre Pearson Chi-Square, Likelihood Ratio veya Fisher's Exact Testleri kullanıldı. İstatistik analizlerde SPSS ${ }^{\circ}$ (Statistical Package for the Social Sciences Inc,
Chicago, ABD) versiyon 17.0 paket programı kullanıldı ve $p$ değeri 0,05 'den küçük ise sonuçlar istatistiksel olarak anlamlı, p değeri 0,05 ile 0,10 arasında ise sonuçlar anlamlılık eğilimi (sınırda anlamlılık) düzeyinde kabul edildi.

\section{BULGULAR}

Tanı anında olguların yaş ortalaması BEO ve NSEO gruplarında sırası ile $33,44 \pm 9,81$ ve $34,76 \pm 10,09$ olarak bulundu ( $\mathrm{p}=0,728)$. BEO'lu olguların altısında $(\% 66,7)$ sağ, üçünde $(33,3)$ ise sol tarafta tutulum saptanırken NSEO'lu olgulardan 17'sinde sağ (\%50), 14'ünde $(\% 41,2)$ sol tarafta, üç olguda $(\% 8,8)$ ise bilateral tutulum saptand. Skrotal ağrı ve şişlik her iki gruptaki hastalarda da en sık saptanan semptom idi. Hastaların başvuru semptomları ve sıklıkları Tablo 1'de sunulmuştur. İstatistiksel olarak anlamlı olmamakla beraber artraljinin BEO'lu, dizürinin ise NSEO'lu olgularda anlamlılık eğilimi düzeyinde daha sık görüldüğü saptandı (p değerleri sırası ile 0,073 ve 0,069). Brusella için risk faktörleri (meslek, pastörize olmayan süt ve süt ürünlerinin tüketimi ve brusellozun hiperendemik olduğu bölgelere seyahat) BEO'lu olguların sekizinde $(\% 88,9)$, NSEO'lu olguların ise beşinde (\%14,7) saptandı $(\mathrm{p}<0,001)$.

Her iki gruptaki hastaların laboratuvar ve skrotal RDUS bulguları Tablo 2 ve 3 'te sunulmuştur. Laboratuvar ve sonografik bulguların görülme sıklığı bakımından iki grup arasında istatistiksel olarak anlamlı bir fark saptanmadı. Ancak, piyüri ve lökositozun NSEO'lu, $5 \mathrm{mg} / \mathrm{dL}$ 'nin üzerinde serum CRP yüksekliğinin ise BEO'lu olgularda anlamlılık eğilimi düzeyinde daha sık görüldüğü saptandı (p değerleri sırası ile; $0,069,0,058$ ve 0,089 ).

Tablo 1. BEO'lu ve NSEO'lu olguların klinik belirtileri

\begin{tabular}{|c|c|c|c|}
\hline & $\begin{array}{c}B E O(n=9) \\
n(\%)\end{array}$ & $\begin{array}{c}\text { NSEO }(n=34) \\
n(\%)\end{array}$ & $p$ değeri \\
\hline Skrotal ağrı & $9(100)$ & $33(97,1)$ & 0,999 \\
\hline Skrotal şişlik & $9(100)$ & $31(91,2)$ & 0,999 \\
\hline Ateş $\left(>38^{\circ} \mathrm{C}\right)$ & $8(88,9)$ & $24(70,6)$ & 0,407 \\
\hline Terleme & $7(77,8)$ & $15(44,1)$ & 0,132 \\
\hline Yorgunluk & $5(55,6)$ & $13(38,2)$ & 0,455 \\
\hline İştahsızlık & $3(33,3)$ & $6(17,7)$ & 0,367 \\
\hline Bulant-Kusma & $2(22,2)$ & $3(8,8)$ & 0,277 \\
\hline Dizüri & $2(22,2)$ & $20(58,8)$ & 0,069 \\
\hline Artralji & $2(22,2)$ & $1(2,9)$ & 0,073 \\
\hline
\end{tabular}


Tablo 2. BEO'lu ve NSEO'lu olgularda saptanan laboratuvar bulguları

\begin{tabular}{lccc}
\hline & $B E O(n=9)$ & NSEO $(n=34)$ & $p$ \\
& $n(\%)$ & $n(\%)$ & değeri \\
\hline Piyüri & $2(22,2)$ & $20(58,8)$ & 0,069 \\
Lökositoz (WBC >10,5×10\%/l) & $3(33,3)$ & $24(70,6)$ & 0,058 \\
Serum CRP düzeyi >5 mg/dL & $9(100)$ & $24(70,6)$ & 0,089 \\
ESH >20 mm/sa & $7(77,8)$ & $25(73,5)$ & 0,999 \\
\hline
\end{tabular}

Tablo 3. BEO'lu ve NSEO'lu olgularda saptanan radyolojik bulgular

\begin{tabular}{|c|c|c|c|}
\hline & $\begin{array}{c}B E O(n=9) \\
n(\%)\end{array}$ & $\begin{array}{c}\operatorname{NSEO}(n=34) \\
n(\%)\end{array}$ & $\begin{array}{c}p \\
\text { değeri }\end{array}$ \\
\hline Skrotal cilt kalınlığında artış & $6(66,7)$ & $24(70,6)$ & 0,999 \\
\hline $\begin{array}{l}\text { Epididim/testiste boyut } \\
\text { artı̧ı }\end{array}$ & $8(88,9)$ & $32(94,1)$ & 0,515 \\
\hline $\begin{array}{l}\text { Epididim/testiste kanlanma } \\
\text { artışı }\end{array}$ & $9(100)$ & $33(97,1)$ & 0,999 \\
\hline Normal ekojenite & $2(22,2)$ & $5(14,7)$ & 0,624 \\
\hline Diffüz heterojen hipoekoik & $5(55,6)$ & $22(64,7)$ & 0,706 \\
\hline Diffüz heterojen hiperekoik & $1(11,1)$ & $6(17,7)$ & 0,999 \\
\hline Fokal parankimal değişiklik & $1(11,1)$ & $1(2,9)$ & 0,379 \\
\hline
\end{tabular}

BEO’lu olgulardan yalnız ikisi $(\% 22,2)$ ilk müracaat anında BEO tanısı alırken, kalan yedisi $(\% 77,8)$ ise NSEO tanısı ile başlanan ampirik tedaviye yanıt alınamaması üzerine yapılan ikincil değerlendirmede BEO tanısı alan olgulardı. Sekiz olguda $(\% 88,9)$ DSÖ’nün önerdiği klasik ikili medikal tedavi (tetrasiklin $2 \times 100 \mathrm{mg} /$ gün ve rifampisin $1 \times 600$ mg/gün; altı hafta) ile şifa sağlanırken, başka bir merkezde yaklaşık dört hafta NSEO tanısı ile ampirik tedavi alan ve tedavi yanıtsızlığı üzerine kliniğimize müracaat ederek BEO tanısı konulan bir olguda $(\% 11,1)$ ise ikili medikal tedaviye yanıt alınamaması ve testiste yaygın nekrotik alanlar görülmesi üzerine orşiektomi yapıldı. NSEO olgularının tamamında ise 2-4 haftalık ampirik medikal tedaviler (kinolonlar, trimetoprin-sulfametoksazol, sefalosporinler, doksisiklin ve bunların çeşitli kombinasyonları) ile komplikasyonsuz olarak şifa sağlandığı saptandı.

\section{TARTIȘMA}

Bruselloz hastalarında sıklıkla sistemik hastalığın bir komponenti olarak görülen epididimo-orşit seyrek olarak yetersiz tedavi sonrası izole relaps veya brusellozun ilk manifestasyonu olarak da görülebilmektedir. ${ }^{[6]}$ Brusellozun ilk klinik bulgusu olarak ortaya çıkan epididimo-orşit klinik pratikte sıklıkla NSEO, tüberküloz epididimo-orşiti, testiküler apse ve testis tümörü ile karıştırılabilmektedir. ${ }^{[3,5]}$ BEO’lu hastalarda tanı/tedavide gecikme veya uygun olmayan tedavi orşiektomi ile sonuçlanabilen testiküler apse, infarkt, atrofi ve nekroza neden olabilmektedir. Ayrıca, uzamış enfeksiyon unilateral olsa dahi antisperm antikorları gelişmesine neden olarak bilateral gonadal hasar, sperm parametrelerinde bozulma ve infertiliteye yol açabilmektedir. ${ }^{[3,4,7]}$ Akıncı ve ark., 15'i enfeksiyondan önce fertil olan 17 BEO'lu olgudan antibiyoterapi öncesinde örnek vermeye uygun 14'ünün sperm parametrelerini tedavi öncesi ve sonrasında değerlendirdikleri çalışmalarında, enfeksiyonun akut fazında tüm olgularda sperm analizinin subnormal olduğunu (aspermi [n: 5], oligospermi [n: 8], motilite bozukluğu [n: 10]), bu bozuklukların dört olguda $(\% 28,6)$ tedavi bitiminde de devam ettiğini bildirmişlerdir. ${ }^{[3]}$

Genç erişkin hastalığı olan BEO genellikle tek taraf$l_{1}$ testiste granülomatöz tipte enflamasyon görülmesi ile karakterizedir. BEO’lu olguların yaklaşık \%10'unda ise bilateral tutulum gözlenmektedir. ${ }^{[8]}$ Literatürle uyumlu olarak yaş ortalaması 33 yıl olan BEO’lu olgularımızın tamamında unilateral testis tutulumu gözledik. Skrotal ağrı ve şişlik BEO'lu olgularda en sık görülen semptomlardır. [3] Olguların hemen tamamında görülen bu semptomlara yaklaşık olarak üç olgudan ikisinde ateş, terleme ve yorgunluk eşlik eder. Artralji, iştahsızlık, bulantı-kusma ve dizüri ise daha az bir sıklıkta bu belirtilere eşlik edebilmektedir. [3,6] Ancak, bu semptomların tamamı, benzer sıklıklarda, NSEO'lu olgularda da görülebilmektedir. ${ }^{[7,9,10]}$ Literatüde BEO'lu olguları NSEO'lu olgulardan ayırmada faydalı olabilecek semptomların varlığını araştıran çalışmalarda yalnız dizüri yokluğunun BEO tanısı lehine olduğu saptanmıştır. [7,10,11] İbrahim ve ark., BEO'lu olguların \%10'unda görülen dizürinin NSEO'lu olguların \%80’inde görüldügüünü bildirmişlerdir. ${ }^{[7]}$ Benzer sonuçlar Papatsoris ve ark. tarafından da bildirilmiştir; gruplardaki dizüri sıklığı sırası ile \%23'e karşılık \%84 (p<0,001). ${ }^{[10]} \mathrm{Bu}$ çalışmaların aksine Khan ve ark., BEO'lu olgularda NSEO'lu olgulardakine benzer sıklıkta dizüri görüldüğünü bildirmiştir (\%62'ye karşılık \%64, p>0,05).[9] Çalışmamızda, BEO ve NSEO gruplarında görülen dizüri sıklıkları bakımından, İbrahim ve Papatsoris'in çalışmalarına benzer sonuçlar elde edildi. Ayrıca çalışmamızda NSEO'lu olgulara kıyasla BEO’lu olgularda artralji görülme sıklığının, anlamlılık eğilimi düzeyinde, daha yüksek olduğu saptandı. Ancak BEO'lu olguların yaklaşık \%20'sinde görülen artraljinin klinik pratikte iki orşit türünü ayırmada çok faydalı olmadığı kanaatindeyiz. BEO olgularının klinik değerlendirmesinde en değerli bulgu hastada bruselloz risk faktörlerinin varlığıdır. ${ }^{[4,12]}$ Özer ve ark., 33 BEO olgusunu inceledikleri çalışmalarında 21 olgunun $(\% 63,6)$ bruselloz risk faktörlerine sahip olduğu bildirmişlermiş. ${ }^{[12]}$ Serimizde ise bu oran \%88,9 olarak saptandi. 
NSEO'nun aksine BEO genellikle idrarda müspet bir bulguya neden olmaz ve idrar analizi ile idrar kültürleri genellikle sterildir. ${ }^{[6]}$ Ancak, literatürde BEO'lu hastaların ortalama \%10-35'inde idrar analizinde piyüri, hematüri, proteinüri veya bunların çeşitli kombinasyonlarının saptandığı bildirilmiştir. ${ }^{[7,10,13]}$ İbrahim ve ark., çalışmalarındaki BEO'lu hastaların tamamında idrar analizinin normal olduğunu NSEO'lu olguların ise $\% 66,7$ 'sinde piyüri saptandığını bildirmişlerdir. ${ }^{[7]}$ Benzer bir başka çalışmada Papatsoris ve ark., 17 BEO'lu hastanın 6'sında (\%35,3), NSEO'lu 141 olgunun ise tamamında piyüri gözlendiğini bildirmişlerdir. ${ }^{[10]}$ Çalışmamızda BEO'lu olgulardaki piyüri sıklığı $(\% 22,2)$ literatürle uyumlu olarak saptanırken bu oran NSEO'lu olgularda, literatürden daha düşük bir düzeyde, \%58,8 olarak tespit edildi. Epididimo-orşitli olgularda piyürinin yokluğu $\mathrm{BEO}$ açısından bir öngörü faktörü olabilir ancak piyüri varlığı $\mathrm{BEO}$ tanısını dışlayamadığı gibi NSEO'lu olguların yaklaşık yarısında da piyüri saptanmayabileceği akılda tutulmalıdır.

Brusellozda tam kan sayımında beyaz küre genellikle normal veya düşüktür. Hastaların yaklaşı $\% 10$ 'unda lökositoz görülür. Bu nedenle lökositoz bruselloz tanısı için belirleyici bir laboratuvar bulgusu olarak kabul edilmemektedir. ${ }^{[1,5]}$ Literatürde BEO'lu olgularda \%70'lere varan lökositoz saptanma oranı bildiren yayınlar olmakla beraber bu oran çoğu seride $\% 10$ ile $\% 30$ arasında bildirilmiştir. ${ }^{[5,7,9]}$ Brusella tanısı koymada tanı değeri olmayan lökosit sayımı BEO'lu olguları NSEO'lu olgulardan ayırmada faydalı görünmektedir. İbrahim ve ark. BEO'lu hastaların \%10'unda NSEO'lu olguların ise \%80'inde lökositoz saptandığını $(\mathrm{p}=0,001)$, BEO ile NSEO ayırımında lökositozun belirleyici bir faktör olabileceğini bildirmişlerdir. ${ }^{[7]}$ Benzer bir diğer çalışmada Yurdakul ve ark. lökositoz görülme sıklığının BEO'lu ve NSEO'lu olgularda istatistiksel anlamlı olarak farklı olduğunu bildirmişlerdir (sırası ile $\% 14$ ve $\% 85$, $\mathrm{p}=0,001) .^{[11]}$ Her ne kadar istatistiksel olarak anlamlılık eğilimi düzeyinde olsa da, çalışmamızda da benzer şekilde NSEO'lu hastalarda BEO'lu hastalara oranla daha yüksek yüzde ile lökositoz görüldüğü saptandı. Epididimo-orşitli bir olguda lökositoz saptanmaması $\mathrm{BEO}$ yönünden uyarıcı bir bulgu olarak görünse de lökositoz varlığı $\mathrm{BEO}$ tanısını dışlayamamaktır.

ESH ve serum CRP düzeyi sistemik inflamatuvar aktivitenin belirteçlerindendir. Literatürde ESH ve serum CRP değerleri yüksek epididimo-orşit olgularının yüzdesi oldukça geniş bir aralıkta bildirilmiş olsa da söz konusu parametreler hem BEO'lu hem de NSEO'lu hastaların önemli bir kısmında yükselmektedir. BEO'lu ve NSEO'lu olguların karşılaştırıldığı çalışmalarda ESH yüksekliğinin her iki grupta benzer bir yüzdede saptandığı bildirilmiştir.
[7,10,11] Bildiğimiz kadarı ile literatürde BEO ve NSEO olgularını serum CRP yüksekliği açısından karşılaştıran yayın bulunmamaktadır. Bu yönü ile bir ilk olan yayınımızda her ne kadar $5 \mathrm{mg} / \mathrm{dL}$ 'nin üzerinde serum CRP yüksekliğinin BEO'lu olgularda NSEO'lu olgulara kıyasla anlamlılık eğilimi düzeyinde daha sık görüldüğünü (\%100'e karşı1ık \%70,6, p=0,089) saptamış olsak da bu farkın klinik pratikte ayırıcı tanıda yol gösterici olamayacağı kanaatindeyiz.

Epididim/testis boyut, damar sayısı ve büyüklügünde artış, heterojenite ve ekojenitede azalma ile artmış skrotal cilt kalınlığı ve reaktif hidrosel NSEO'nun klasik ultrasonografi bulgularıdır. Ancak, bu bulguların hiçbiri spesifik değildir ve inflamatuvar sürecin erken dönemlerinde görülemeyebileceği gibi kanama varlığında ekojenitede artma dahi görülebilmektedir. ${ }^{[14]}$ Birçok çalışmada BEO'lu olgularda NSEO'ya benzer ultrasonografik bulgular saptanmıştır. [14-16] Deveer ve ark., skrotal B-mod ve RDUS kullanarak BEO ve NSEO'lu olguların ultrasonografik bulgularını karşılaştırdıkları çalışmada testis boyutları, parankimal tutulumları, akım hızları ve Rezistivite İndeksi değerlerinde farklılık saptamamışlardır. ${ }^{[14]} \mathrm{Bu}$ çalışmaların aksine, Öztürk ve ark., brusellozun endemik olduğu bölgelerde skrotal enfeksiyon gelişen hastalarda ultrasonografik incelemede heterojenite, fokal ekojenite farklılıkları ve granülarite ve/veya septasyonun eşlik ettiği hidrosel saptanması halinde bu hastaların BEO olma olasılı̆̆ının NSEO olma olasılığından daha fazla olduğunu bildirmişlerdir. ${ }^{[17]} \mathrm{Biz}$ de çalışmamızda BEO'lu olgularda NSEO'lu olgulardan fark$l_{1}$ bir ultrasonografi bulgusu saptamadik.

\section{SONUC}

Bruselloz tanısı serolojik ve mikrobiyolojik testlerle konulmaktadır. Epididimo-orşitli hastaların temel değerlendirmesinde yer alan hiçbir klinik, laboratuvar veya radyolojik bulgu brusellozun ilk manifestasyonu olarak ortaya çıan epidimo-orşiti ayırmada yeterli tanısal değere sahip değildir. $\mathrm{Bu}$ nedenle olguların birçoğunda tanı, NSEO tanısı ile verilen ampirik medikal tedaviye yanıtsızlık sonrasında yapılan, ikincil değerlendirme aşamasında konulabilmektedir. Epididimo-orşitli tüm olgulardan öykü alınırken bruselloz risk faktörlerinin sorgulanması BEO'nun erken tanısında en önemli aşamadır. Ayrıca, dizüri, piyüri ve lökositozu olmayan, artraljinin eşlik ettiği epididimo-orşit olgularında BEO ayırıcı tanısı açısından daha dikkatli olunmalıdır. BEO'nun erken tanı ve uygun tedavisi hastalarda sperm parametrelerinde bozulma ve hatta orşiektomi gereksinimine neden olabilen testiküler hasarın önüne geçilebilmesi için son derece önemlidir. 
Hakem Değerlendirmesi

Dış bağımsız

Çıkar Çatışması

Yazarlar çıkar ilişkisi olmadığını beyan etmişlerdir.

\section{Finansal Destek}

Herhangi bir mali destek alınmamıștır.

\section{Peer-review}

Externally peer-reviewed.

Conflict of Interest

No conflict of interest was declared by the authors.

Financial Disclosure

No financial disclosure was received

\section{KAYNAKLAR}

1. Kandemir Ö. Bruselloz. Turkiye Klinikleri J Inf Dis-Special Topics 2015;8:1-9.

2. Dean AS, Crump L, Greter H, Hattendorf J, Schelling E, Zinsstag J. Clinical manifestations of human brucellosis: a systematic review and meta-analysis. PLoS Negl Trop Dis 2012;6:e1929. [CrossRef]

3. Akıncı E, Bodur H, Çevik MA, Erbay A, Eren SS, Zıraman I, et al. A complication of brucellosis: epididymoorchitis. Int J Infect Dis 2006;10:171-7. [CrossRef]

4. Memish ZA, Venkatesh S. Brucellar epididymo-orchitis in Saudi Arabia: a retrospective study of 26 cases and review of the literature. BJU International 2001;88:72-6. [CrossRef]

5. Turunç T, Kuzgunbay B, Turunç T. Epididimoorşit Nedeniyle Başvuran Her Hastada Rutin Brusella Aglütinasyon Testi İstenmeli mi? Van Tip Dergisi 2010;17:136-9.

6. Karaköse A, Yuksel MB, Aydoğdu O, Hamidi AA. Epididymoorchitis as the first finding in patients with brucellosis. Adv Urol 2013;2013. [CrossRef]
7. Ibrahim AI, Awad R, Shetiy SD, Saad M, Bilal NE. Genito-urinary complications of brucellosis. Br J Urol 1988;61:294-8. [CrossRef]

8. Bosilkovski M, Kamiloski V, Miskova S, Balalovski D, Kotevska V, Petrovski M. Testicular infection in brucellosis: Report of 34 cases. J Microbiol Immunol Infect 2018;51:82-7. [CrossRef]

9. Khan MS, Humayoon MS, Al Manee MS. Epididymo-orchitis and Brucellosis. Br J Urol 1989;63:87-9. [CrossRef]

10. Papatsoris AG, Mpadra FA, Karamouzis MV, Frangides CY. Endemic brucellar epididymo-orchitis: a 10-year experience. Int J Infect Dis 2002;6:309-13. [CrossRef]

11. Yurdakul T, Sert U, Acar A, Karalezli G, Akçetin Z. Epididymoorchitis as a complication of brucellosis. Urol Int 1995;55:141-2. [CrossRef]

12. Özer S, Oltan N, Gençer S. Bruselloz: 33 olgunun değerlendirilmesi. Klimik Derg 1998;11:82-4.

13. Navarro-Martínez A, Solera J, Corredoira J, Beato JL, MartínezAlfaro E, Atiénzar M, Ariza J. Epididymoorchitis due to Brucella mellitensis: a retrospective study of 59 patients. Clin Infect Dis 2001;33:2017-22. [CrossRef]

14. Deveer M, Zıraman İ. Brusella Epididimoorşiti ile Nonspesifik Epididimoorşitin Sonografik Karşılaştırılması. Muğla Sıtkı Koçman Üniversitesi Tıp Dergisi 2015;2:1-6.

15. Bayram MM, Kervancğlu R. Scrotal gray-scale and color Doppler sonographic findings in genitourinary brucellosis. J Clin Ultrasound 1997;25:443-7. [CrossRef]

16. Patel PJ, Kolawole TM, Sharma N, al-Faqih S. Sonographic findings in scrotal brucellosis. J Clin Ultrasound 1988;16:483-6. [CrossRef]

17. Ozturk A, Ozturk E, Zeyrek F, Onur K, Sirmatel O, Kat N. Comparison of brucella and non-specific epididymorchitis: gray scale and color Doppler ultrasonographic features. Eur J Radiol 2005;56:256-62. [CrossRef] 